\title{
ENZYME MARKERS ACTIVITY AND BILE FORMATION FUNCTION OF LIVER IN CASES OF TUBERCULOSTATICS AND HEXAVALENT CHROMIUM COMPOUNDS AFFECTION IN RATS
}

\author{
N. I. Burmas, L. S. Fira, P. H. Lyhackyy \\ I. HORBACHEVSKY TERNOPIL STATE MEDICAL UNIVERSITY, TERNOPIL, UKRAINE
}

Background. Currently, the growing incidence of toxic lesions of the liver is associated with industrial chemicalization and uncontrolled use of hepatotoxic drugs in everyday life. There are about one thousand drugs with high or low hepatotoxicity, such as anti-TB drugs.

Objective. In this research we studied the intracellular enzymes activity and bile formation function of the liver in rats of different ages in cases of tuberculostatic (isoniazid and rifampicin) affection and chromium (potassium dichromate) intoxication.

Methods. The experimental affection of rats of different ages was performed by combined injection of hexavalent chromium compounds (a solution of potassium dichromate, $3 \mathrm{mg} / \mathrm{kg}$ ), isoniazid $(0.05 \mathrm{~g} / \mathrm{kg})$ and rifampicin $(0.25 \mathrm{~g} / \mathrm{kg})$. On the $7^{\text {th }}$ and $14^{\text {th }}$ days the rats were injected with enterosorbent Sorbex $(150 \mathrm{mg} / \mathrm{kg})$. Enzyme markers activity of the liver was evaluated due to alanine and aspartate aminotransferases (ALT and AST) and alkaline phosphatase (ALP) rates. Bile formation function of the liver was evaluated by total bilirubin and bile acids content in blood.

Results. The disorders in hepatocytes plasma membranes permeability were defined by the increased rates of ALT, AST and alkaline phosphatase in blood serum which were decreased in the liver. It was determined that total bilirubin and bile acids content in blood serum of the affected animals increased. It influenced hepatocytes excretion in bile capillaries and caused cholestasis and revenues decrease in bile.

Conclusions. The most significant metabolic disorders in cases of chrome-isoniazid-rifampicin affection were defined in immature and senior animals in comparison with mature animals.

KEY WORDS: isoniazid, rifampicin, hexavalent chromium compounds, liver enzymes, bile formation.

\section{Introduction}

Considering the role of liver in the chemical compounds metabolism we can assert that there are no drugs that in certain conditions would not cause impairment. More and more information about their hepatotoxic effect indicates that medical affection of the liver is one of the major problems of hepatology [1-3]. Antituberculosis drugs are of great interest [4-6].

According to the Centre of monitoring of adverse reactions of drugs (2007), isoniazid $29.2 \%$, rifampicin $-26.7 \%$, capreomycin $-17.1 \%$, ethambutol $-10.2 \%$ dominate among monopreparations in high incidence of the adverse

Address for correspondence: Nataliya Burmas, Department of General Chemistry, I. Horbachevsky Ternopil State Medical University, 1 Maidan Voli, Ternopil, Ukraine, 46001 Tel.: +380976123434

E-mail: burmas@tdmu.edu.ua reactions in world [5]. Thus, the risk of the development of hepatitis increases in patients who take rifampicin together with isoniazid. In this case hepatitis incidence is $5-8 \%$. During the isoniazid monotherapy, the incidence of hepatitis is $1.2 \%$, but during the rifampin monotherapy $-0.3 \%[4]$.

According to the researches $[7,8]$, the hepatotoxicity of isoniazid may be developed in two ways: 1 . the accumulation of free radicals with activation of lipid peroxidation and the formation of reactive metabolites: acetylisoniazid, hydrazine, monoacetylhydrazine; 2 . the increased activity of $\mathrm{N}$-acetylisoniazid by $\mathrm{N}$-hydroxylation and formation of acetyl radical and acetyl carbonium ion.

The metabolism of acetyl hydrazine and microsomal monooxygenases cause hepatotoxic effect as a result of the covalent addition of 
acetyl groups to the liver proteins [7], which manifest as temporary asymptomatic increase of transaminases activity. The hepatotoxicity of rifampin is also due to the formation of toxic metabolites as a result of its deacetylation in the liver that leads to hepatocytes dystrophy $[9,10]$.

However, increasing saturation of the environment by the compounds of heavy metals leads to the accumulation of these compounds in human bodies, of those who live on the contaminated areas from early childhood [11-13]. According to some studies, in the future the compounds of heavy metals as the threat for the environment can become the urgent matter, leaving nuclear stations wastes and organic anthropogenic pollution behind [13].

Today Chromium (VI) is recognized by the International Agency of the Cancer Researches of the European Union to be one of six chemical elements (Arsenic, Beryllium, Cadmium, Cobalt, Nickel and Chromium) that reveal the carcinogenic effect on human body $[14,15]$. The influence of the compounds of Chromium (VI) is accompanied by toxic effects and serious internal organs (kidneys, lungs, liver) damage.

But, the recent studies do not provide full concept of the of liver enzymes activity and its influence on bile formation function in cases of combined effect of hexavalent chromium compounds on age-dependent isoniazid-rifampicin destruction of the body, which is presented in this research.

\section{Materials and Methods}

The experiments were conducted on outbred white male rats of three age groups: the $1^{\text {st }}$ group - immature (3-month-old animals, 90-110 g in weight); $2^{\text {nd }}$ group - mature (6-month-old animals, $150-170 \mathrm{~g}$ in weight); and the $3^{\text {rd }}$ group - senile (18-months-old animals, 280-300 $\mathrm{g}$ in weight). The rats were kept on a standard diet at the vivarium of Ternopil State Medical University.

The manipulations on the animals were carried out according to the Article 26 of the Law of Ukraine "On protection of cruelty to animals" from 21.02.2006. No. 3447-IV, "European Convention on protection of vertebrate animals used for experimental and other scientific purposes", "General ethical principles of the experiments on animals", approved 20.09.2001 during the $1^{\text {st }}$ Ukrainian National Congress on Bioethics considering regulations of NIH Guide on Care and Use of Laboratory Animals [16].
The experimental toxic affection of the animals was simulated by combined effect of hexavalent chromium compounds, isoniazid and rifampicin. Hexavalent chromium compounds were administered intragastrically to animals every day for one group by the solution of potassium dichromate, $3 \mathrm{mg} / \mathrm{kg}$. For another group on the $7^{\text {th }}$ and $14^{\text {th }}$ days isoniazid and rifampicin by metallic probe in aqueous solution, $0.05 \mathrm{~g} / \mathrm{kg}$ and $0.25 \mathrm{~g} / \mathrm{kg}$ accordingly, were administered intragastrically. For combined action, the xenobiotics mentioned above were administered in the same doses.

Euthanasia was performed by means of thiopental sodium on the $7^{\text {th }}$ and $14^{\text {th }}$ days from the first day of xenobiotics administration. The study of liver homogenate and blood serum was performed. The blood was taken from the heart of animals by centrifugation at $3000 \mathrm{rev} /$ min during $30 \mathrm{~min}$. The obtained blood serum, sedimentary liquid, was used for researches. Liver (250 mg) was put into 10\% homogenate and different homogenisation methods were used after previous perfusion in physiological solution.

The activity of liver enzyme markers was determined by the rate of aminotransferases (ALT and AST) and an alkaline phosphatase (ALP) (the reagents of OOO NPP Filisit- Diagnostics, Ukraine) in blood serum and liver homogenate. The evaluation of ALT rate was conducted by compound of 2-oxoglutaric acid and L-alanine, which under the influence of alanine aminotransferase formed L-glutamic and pyruvic acids. The interaction of pyruvic acid and 2.4-dynitrophenylhydrazine in alkaline medium formed 2.4-dynitrophenylhydrazones that had high coefficient of the molar extinction, so its optical density registered on the FEC was directly proportional to the activity of the enzyme.

The enzyme activity was estimated by the calibration graph due to the content of pyruvic acid in $\mathrm{mkmol} /(\mathrm{L} \cdot \mathrm{h})$ [17]. AST rate was evaluated by optical density measuring of 2.4 nitrophenylhydrazones of 2-oxoglutaric and pyruvic acids in alkaline medium. Hydrazone of pyruvic acid has a higher coefficient of the molar extinction, so there is a directly proportional relationship of optical density of the reaction solution to the enzyme activity. The enzyme activity was evaluated by the calibration graph due to the content of pyruvic acid, $\mathrm{mkmol} /(\mathrm{L} \cdot \mathrm{h})$ [17]. Estimation of the alkaline phosphatase rate was based on the property of the enzyme to hydrolyse the etheric bond in $\beta$-glycero- 
phosphate and eliminate the phosphoric acid. Phosphorus was determined by colorimetric method due to the reaction with molybdenum reagent in the presence of a reducing eikonogen or ascorbic acid. The product of reaction was molybdenum blue; its colour intensity was directly proportional to the amount of phosphorus in the simple evaluation of the enzyme activity [18].

The bile formation function of the liver in the animals was defined by the content of total bilirubin and bile acids in blood serum. The content of total bilirubin was determined by caffeine reagent, which together with diazotized sulphanilic acid formed azobilirubin of pinkpurple colour. The colour intensity of this solution was directly proportional to the concentration of total bilirubin in the sample. Evaluation of total bilirubin in blood serum was performed by the calibration graph, $\mathrm{mmol} / \mathrm{L}$ [18]. Determination of bile acids content was based on the reaction of colour products formation by condensation, which interacted with bile acids and oxymethyl furfural. These solutions were obtained from fructose. They are the products of hydrolysis by adding concentrated sulfuric acid to sucrose. Bile acids content was evaluated by the calibration graph due to the tauroholic acid content, $\mathrm{g} / \mathrm{L}$ [18].

The statistical processing of the results was performed on a PC by means of programs "Microsoft Excel" and "STATISTICA 6.0" on the basis of arithmetic middling and errors according to Student's t-test [19]. The changes were considered to be reliable at $p \leq 0.05$.

\section{Results}

We noted the increased ALT rate (Table 1) in the blood serum of animal groups of all ages. It was the highest in rats affected by tuberculostatics and potassium dichromate. On the $14^{\text {th }}$ day of xenobiotics administration the rate increased in 2.9 times in immature animals in comparison with the control group, in 2.5 times - in mature animals and in 3.2 times - in senior animals. The mature animals, which were affected by hexavalent chromium compounds, proved to be the least sensitive. Their affection rate exceeded the normal range in 2.3 times.

In the immature rats the ALT rate increased by $120 \%$ on the $7^{\text {th }}$ day of the research and by $145 \%$ - on the $14^{\text {th }}$ day of the affection by isoniazid and rifampicin, in the mature animals this rate exceeded the level of the intact control by $30 \%$ on the $7^{\text {th }}$ day and by $128 \%$ till the end of the experiment.

The senior animals were more sensitive to anti-TB drugs. ALT rate in blood serum increased by $181 \%$ on the $14^{\text {th }}$ day after the affection.

The most significant changes were observed in the liver of the senior animals which underwent the aforementioned xenobiotics

Table 1. Alanine aminotransferase rate in blood serum $(\mathbf{m k m o l} / \mathrm{L} \cdot \mathrm{h})$ and liver $(\mathrm{mkmol} / \mathrm{kg} \cdot \mathbf{h})$ of rats affected by isoniazid, rifampicin and hexavalent chromium compounds, $(\mathrm{M} \pm \mathrm{m})$

\begin{tabular}{|c|c|c|c|c|c|c|c|}
\hline \multirow{4}{*}{$\begin{array}{l}\text { Research } \\
\text { material }\end{array}$} & \multirow{4}{*}{ Group of animals } & \multicolumn{6}{|c|}{ Age group of animals } \\
\hline & & \multicolumn{2}{|c|}{ immature } & \multicolumn{2}{|c|}{ mature } & \multicolumn{2}{|c|}{ senior } \\
\hline & & \multicolumn{6}{|c|}{ Research duration, days } \\
\hline & & $7^{\text {th }}$ & $14^{\text {th }}$ & $7^{\text {th }}$ & $14^{\text {th }}$ & $7^{\text {th }}$ & $14^{\text {th }}$ \\
\hline \multirow{4}{*}{$\begin{array}{l}\text { blood } \\
\text { serum }\end{array}$} & intact control, $\mathrm{n}=6$ & \multicolumn{2}{|c|}{$0.83 \pm 0.05$} & \multicolumn{2}{|c|}{$2.96 \pm 0.18$} & \multicolumn{2}{|c|}{$2.34 \pm 0.15$} \\
\hline & $\begin{array}{l}\text { affected by potassium } \\
\text { dichromate, } n=6\end{array}$ & $\begin{array}{l}1.51 \pm \\
0.10 *\end{array}$ & $\begin{array}{l}1.93 \pm \\
0.16 *\end{array}$ & $\begin{array}{l}4.03 \pm \\
0.32 *\end{array}$ & $\begin{array}{l}6.66 \pm \\
0.17^{*}\end{array}$ & $\begin{array}{l}3.75 \pm \\
0.36 *\end{array}$ & $\begin{array}{l}6.16 \pm \\
0.37 *\end{array}$ \\
\hline & $\begin{array}{l}\text { affected by isoniazid } \\
\text { and rifampicin, } n=6\end{array}$ & $\begin{array}{l}1.83 \pm \\
0.11 *\end{array}$ & $\begin{array}{l}2.03 \pm \\
0.20 *\end{array}$ & $\begin{array}{l}3.84 \pm \\
0.24 *\end{array}$ & $\begin{array}{l}6.74 \pm \\
0.26 *\end{array}$ & $\begin{array}{l}4.44 \pm \\
0.32 *\end{array}$ & $\begin{array}{l}6.58 \pm \\
0.30 *\end{array}$ \\
\hline & $\begin{array}{l}\text { affected by potassium } \\
\text { dichromate, isoniazid } \\
\text { and rifampicin, } n=6\end{array}$ & $\begin{array}{l}2.21 \pm \\
0.12 *\end{array}$ & $\begin{array}{l}2.38 \pm \\
0.14 *\end{array}$ & $\begin{array}{l}4.69 \pm \\
0.19 *\end{array}$ & $\begin{array}{l}7.46 \pm \\
0.42 *\end{array}$ & $\begin{array}{l}5.87 \pm \\
0.30 *\end{array}$ & $\begin{array}{l}7.57 \pm \\
0.26 *\end{array}$ \\
\hline \multirow[t]{4}{*}{ liver } & intact control, $\mathrm{n}=6$ & \multicolumn{2}{|c|}{$5.40 \pm 0.12$} & \multicolumn{2}{|c|}{$8.30 \pm 0.21$} & \multicolumn{2}{|c|}{$6.08 \pm 0.33$} \\
\hline & $\begin{array}{c}\text { affected by potassium } \\
\text { dichromate, } n=6\end{array}$ & $\begin{array}{l}3.96 \pm \\
0.26 *\end{array}$ & $\begin{array}{l}2.97 \pm \\
0.16 *\end{array}$ & $\begin{array}{l}6.55 \pm \\
0.23 *\end{array}$ & $\begin{array}{l}3.96 \pm \\
0.26 *\end{array}$ & $\begin{array}{l}2.97 \pm \\
0.16 *\end{array}$ & $\begin{array}{l}6.55 \pm \\
0.23 *\end{array}$ \\
\hline & $\begin{array}{l}\text { affected by isoniazid } \\
\text { and rifampicin, } n=6\end{array}$ & $\begin{array}{l}3.68 \pm \\
0.20 *\end{array}$ & $\begin{array}{l}2.83 \pm \\
0.11 *\end{array}$ & $\begin{array}{l}6.48 \pm \\
0.27 *\end{array}$ & $\begin{array}{l}3.68 \pm \\
0.20 *\end{array}$ & $\begin{array}{l}2.83 \pm \\
0.11 *\end{array}$ & $\begin{array}{l}6.48 \pm \\
0.27 *\end{array}$ \\
\hline & $\begin{array}{l}\text { affected by potassium } \\
\text { dichromate, isoniazid } \\
\text { and rifampicin, } n=6\end{array}$ & $\begin{array}{l}3.18 \pm \\
0.22 *\end{array}$ & $\begin{array}{l}2.42 \pm \\
0.12 *\end{array}$ & $\begin{array}{l}5.78 \pm \\
0.31 *\end{array}$ & $\begin{array}{l}3.18 \pm \\
0.22 *\end{array}$ & $\begin{array}{l}2.42 \pm \\
0.12 *\end{array}$ & $\begin{array}{l}5.78 \pm \\
0.31 *\end{array}$ \\
\hline
\end{tabular}

Note: here and in the following tables * - significant differences between the animals of intact controls and the affected animals, $\mathrm{p} \leq 0.05$. 
compounds. ALT rate decreased till the end of the experiment by $58 \%(p \leq 0.05)$ in this group, when in the immature group - by $55 \%$, in the mature one - by $45 \%$ in comparison with animals of the intact control.

In blood serum of the experimental animals, affected by $\mathrm{K}_{2} \mathrm{Cr}_{2} \mathrm{O}_{7}$, the AST rate was gradually increasing and reached the highest rate at the end of the experiment by $251 \%$ in the immature animals, by $181 \%$ - in the mature animals and $267 \%$ - in the senior animals if compared to the control group of animals (Table 2). In the immature and mature rats AST rate increased in 3.0 and 2.1 times accordingly in comparison with the control group.

During the research the decrease in AST rate in liver of the affected animals of all age groups was determined (Table 2 ). In the immature animals the activity of this enzyme decreased by $17 \%$ on the $7^{\text {th }}$ day of the research after the administration of $\mathrm{K}_{2} \mathrm{Cr}_{2} \mathrm{O}_{7}$, in the mature animals - by $33 \%$ and in the senior animals - by $39 \%$. It was proved that the accumulation of heavy metals, which got into the body of animals from the environment, took place in hepatocytes [11, 12].

We studied alkaline phosphatase rate in blood serum and liver of the affected rats (Table 3). It was established that this enzyme is a marker of liver disorder and indicates the inflammation in it.

The administration of potassium dichromate into the body of the immature animals caused the increase of alkaline phosphatase rate in blood serum in 1.3 times on the $7^{\text {th }}$ day of the experiment, in the mature animals - in 1.5 times and in the senior animals - in 1.3 times, that caused toxic affection of liver. These changes were significant $(p \leq 0.05)$.

We evidenced the highest rate of alkaline phosphatase in blood serum of the immature animals after combined effect of potassium dichromate, isoniazid and rifampicin, which was $100 \%$ on the $7^{\text {th }}$ day after affection and $127 \%$ on the $14^{\text {th }}$ day in comparison with the animals of the intact control.

In liver of the affected animals the ALP rate decreased during the experiment in all experimental groups (Table 3). The lowest rate of alkaline phosphatase was on the $14^{\text {th }}$ day of the research in the mature animals after the combined effect of xenobiotics (772.86 \pm 29.62$)$ $\mathrm{nmol} /(\mathrm{s} \cdot \mathrm{g})$ that is in 1.7 times lower than in the control group (1338.23 $\pm 54.21 \mathrm{nmol} /(\mathrm{s} \cdot \mathrm{g})$.

We evidenced a significant increase $(p \leq 0.05)$ in total bilirubin content in blood serum of the animals of all age groups in comparison with control rats (Table 4). On the $14^{\text {th }}$ day of the experiment the total bilirubin content increased by $53 \%$ in the immature animals, by $40 \%$ in the mature ones and by $28 \%$ in the senior rats after the affection with anti-TB drugs in comparison with the animals of the intact control.

We evidenced the highest content of total bilirubin at the end of the research in the mature animals after combined administration of $\mathrm{K}_{2} \mathrm{Cr}_{2} \mathrm{O}_{7}$, isoniazid and rifampicin, which was $206 \%$ in comparison with intact animals that is

Table 2. Aspartate aminotransferase rate in blood serum ( $\mathrm{mkmol} / \mathrm{L} \cdot \mathrm{h})$ and liver $(\mathrm{mkmol} / \mathrm{kg} \cdot \mathrm{h})$ of rats affected by isoniazid, rifampicin and hexavalent chromium compounds, $(\mathrm{M} \pm \mathrm{m})$

\begin{tabular}{|c|c|c|c|c|c|c|c|}
\hline \multirow{4}{*}{$\begin{array}{l}\text { Research } \\
\text { material }\end{array}$} & \multirow{4}{*}{ Group of animals } & \multicolumn{6}{|c|}{ Age group of animals } \\
\hline & & \multicolumn{2}{|c|}{ immature } & \multicolumn{2}{|c|}{ mature } & \multicolumn{2}{|c|}{ senior } \\
\hline & & \multicolumn{6}{|c|}{ Research duration, days } \\
\hline & & $7^{\text {th }}$ & $14^{\text {th }}$ & $7^{\text {th }}$ & $14^{\text {th }}$ & $7^{\text {th }}$ & $14^{\text {th }}$ \\
\hline \multirow{4}{*}{$\begin{array}{l}\text { blood } \\
\text { serum }\end{array}$} & intact control, $n=6$ & \multicolumn{2}{|c|}{$0.70 \pm 0.06$} & \multicolumn{2}{|c|}{$0.64 \pm 0.04$} & \multicolumn{2}{|c|}{$1.05 \pm 0.20$} \\
\hline & $\begin{array}{l}\text { affected by potassium } \\
\text { dichromate, } n=6\end{array}$ & $\begin{array}{l}0.94 \pm \\
0.04 *\end{array}$ & $\begin{array}{l}1.76 \pm \\
0.08 *\end{array}$ & $\begin{array}{l}0.93 \pm \\
0.05 *\end{array}$ & $\begin{array}{l}1.16 \pm \\
0.04 *\end{array}$ & $\begin{array}{l}2.04 \pm \\
0.14 *\end{array}$ & $\begin{array}{l}2.80 \pm \\
0.09 *\end{array}$ \\
\hline & $\begin{array}{l}\text { affected by isoniazid and } \\
\text { rifampicin, } n=6\end{array}$ & $\begin{array}{l}1.05 \pm \\
0.05 *\end{array}$ & $\begin{array}{l}1.84 \pm \\
0.10 *\end{array}$ & $\begin{array}{l}1.10 \pm \\
0.05 *\end{array}$ & $\begin{array}{l}1.21 \pm \\
0.06 *\end{array}$ & $\begin{array}{l}2.61 \pm \\
0.09 *\end{array}$ & $\begin{array}{l}3.40 \pm \\
0.14^{*}\end{array}$ \\
\hline & $\begin{array}{c}\text { affected by potassium } \\
\text { dichromate, isoniazid and } \\
\text { rifampicin, } \mathrm{n}=6\end{array}$ & $\begin{array}{l}1.21 \pm \\
0.07 *\end{array}$ & $\begin{array}{l}2.07 \pm \\
0.14 *\end{array}$ & $\begin{array}{l}1.19 \pm \\
0.06 *\end{array}$ & $\begin{array}{l}1.34 \pm \\
0.08 *\end{array}$ & $\begin{array}{l}3.22 \pm \\
0.14 *\end{array}$ & $\begin{array}{l}3.85 \pm \\
0.18 *\end{array}$ \\
\hline \multirow[t]{4}{*}{ liver } & intact control, $\mathrm{n}=6$ & \multicolumn{2}{|c|}{$1.21 \pm 0.11$} & \multicolumn{2}{|c|}{$2.66 \pm 0.06$} & \multicolumn{2}{|c|}{$2.48 \pm 0.12$} \\
\hline & $\begin{array}{c}\text { affected by potassium } \\
\text { dichromate, } n=6\end{array}$ & $\begin{array}{l}1.01 \pm \\
0.05 \\
\end{array}$ & $\begin{array}{l}0.91 \pm \\
0.02 *\end{array}$ & $\begin{array}{l}1.79 \pm \\
0.06 *\end{array}$ & $\begin{array}{l}1.44 \pm \\
0.05 * \\
\end{array}$ & $\begin{array}{l}1.52 \pm \\
0.04 *\end{array}$ & $\begin{array}{l}1.25 \pm \\
0.04 *\end{array}$ \\
\hline & $\begin{array}{c}\text { affected by isoniazid and } \\
\text { rifampicin, } n=6\end{array}$ & $\begin{array}{l}1.02 \pm \\
0.04\end{array}$ & $\begin{array}{l}0.86 \pm \\
0.03 *\end{array}$ & $\begin{array}{l}1.66 \pm \\
0.10 *\end{array}$ & $\begin{array}{l}1.34 \pm \\
0.07 *\end{array}$ & $\begin{array}{l}1.45 \pm \\
0.04 *\end{array}$ & $\begin{array}{l}1.18 \pm \\
0.03 *\end{array}$ \\
\hline & $\begin{array}{l}\text { affected by potassium } \\
\text { dichromate, isoniazid and } \\
\text { rifampicin, } n=6\end{array}$ & $\begin{array}{l}0.87 \pm \\
0.03 *\end{array}$ & $\begin{array}{l}0.75 \pm \\
0.04 *\end{array}$ & $\begin{array}{l}1.45 \pm \\
0.10 *\end{array}$ & $\begin{array}{l}1.25 \pm \\
0.06 *\end{array}$ & $\begin{array}{l}1.34 \pm \\
0.04 *\end{array}$ & $\begin{array}{l}1.13 \pm \\
0.04^{*}\end{array}$ \\
\hline
\end{tabular}


Table 3. Alkaline phosphatase rate in blood serum (nmol/s·L) and liver ( $\mathrm{nmol} / \mathrm{s} \cdot \mathrm{g})$ of rats affected by isoniazid, rifampicin and hexavalent chromium compounds, $(\mathrm{M} \pm \mathrm{m})$

\begin{tabular}{|c|c|c|c|c|c|c|c|}
\hline \multirow{4}{*}{$\begin{array}{l}\text { Research } \\
\text { material }\end{array}$} & \multirow{4}{*}{ Group of animals } & \multicolumn{6}{|c|}{ Age group of animals } \\
\hline & & \multicolumn{2}{|c|}{ immature } & \multicolumn{2}{|c|}{ mature } & \multicolumn{2}{|c|}{ senior } \\
\hline & & \multicolumn{6}{|c|}{ Research duration, days } \\
\hline & & $7^{\text {th }}$ & $14^{\text {th }}$ & $7^{\text {th }}$ & $14^{\text {th }}$ & $7^{\text {th }}$ & $14^{\text {th }}$ \\
\hline \multirow{4}{*}{$\begin{array}{l}\text { blood } \\
\text { serum }\end{array}$} & intact control, $n=6$ & \multicolumn{2}{|c|}{$1924.64 \pm 113.32$} & \multicolumn{2}{|c|}{$2405.80 \pm 159.13$} & \multicolumn{2}{|c|}{$3007.25 \pm 240.58$} \\
\hline & $\begin{array}{l}\text { affected by potassium } \\
\text { dichromate, } n=6\end{array}$ & $\begin{array}{c}2766.67 \pm \\
159.13^{*}\end{array}$ & $\begin{array}{l}3518.48 \pm \\
227.04 *\end{array}$ & $\begin{array}{l}3488.41 \pm \\
206.60 *\end{array}$ & $\begin{array}{c}3849.28 \pm \\
184.40 *\end{array}$ & $\begin{array}{l}3939.49 \pm \\
205.29 *\end{array}$ & $\begin{array}{l}4360.51 \pm \\
225.44 *\end{array}$ \\
\hline & $\begin{array}{l}\text { affected by isoniazid } \\
\text { and rifampicin, } n=6\end{array}$ & $\begin{array}{c}3247.83 \pm \\
192.09 *\end{array}$ & $\begin{array}{l}3849.28 \pm \\
206.60 *\end{array}$ & $\begin{array}{l}4210.15 \pm \\
159.13 *\end{array}$ & $\begin{array}{c}4540.94 \pm \\
142.96 *\end{array}$ & $\begin{array}{l}4330.43 \pm \\
208.35 *\end{array}$ & $\begin{array}{c}4781.52 \pm \\
137.81 *\end{array}$ \\
\hline & $\begin{array}{l}\text { affected by potassium } \\
\text { dichromate, isoniazid } \\
\text { and rifampicin, } n=6\end{array}$ & $\begin{array}{c}3849.28 \pm \\
159.13^{*}\end{array}$ & $\begin{array}{c}4360.51 \pm \\
182.92^{*}\end{array}$ & $\begin{array}{c}4691.30 \pm \\
104.17 *\end{array}$ & $\begin{array}{c}4751.45 \pm \\
144.85 *\end{array}$ & $\begin{array}{c}4961.96 \pm \\
137.81 *\end{array}$ & $\begin{array}{c}5352.90 \pm \\
159.13 *\end{array}$ \\
\hline \multirow[t]{4}{*}{ liver } & intact control, $\mathrm{n}=6$ & \multicolumn{2}{|c|}{$739.78 \pm 30.90$} & \multicolumn{2}{|c|}{$1338.23 \pm 54.21$} & \multicolumn{2}{|c|}{$1705.11 \pm 74.21$} \\
\hline & $\begin{array}{c}\text { affected by potassium } \\
\text { dichromate, } n=6\end{array}$ & $\begin{array}{l}634.53 \pm \\
20.53 *\end{array}$ & $\begin{array}{c}610.47 \pm \\
14.30 * \\
\end{array}$ & $\begin{array}{c}1004.42 \pm \\
50.54^{*}\end{array}$ & $\begin{array}{l}878.12 \pm \\
33.16 *\end{array}$ & $\begin{array}{c}1377.32 \pm \\
41.84 *\end{array}$ & $\begin{array}{c}1305.14 \pm \\
19.02 *\end{array}$ \\
\hline & $\begin{array}{l}\text { affected by isoniazid } \\
\text { and rifampicin, } n=6\end{array}$ & $\begin{array}{c}562.35 \pm \\
19.44 *\end{array}$ & $\begin{array}{c}496.20 \pm \\
20.17 *\end{array}$ & $\begin{array}{l}941.27 \pm \\
38.82 *\end{array}$ & $\begin{array}{l}836.01 \pm \\
35.68 *\end{array}$ & $\begin{array}{c}1341.23 \pm \\
30.79 *\end{array}$ & $\begin{array}{c}1235.14 \pm \\
16.64 *\end{array}$ \\
\hline & $\begin{array}{l}\text { affected by potassium } \\
\text { dichromate, isoniazid } \\
\text { and rifampicin, } n=6\end{array}$ & $\begin{array}{c}514.24 \pm \\
21.22 *\end{array}$ & $\begin{array}{c}457.10 \pm \\
13.72 *\end{array}$ & $\begin{array}{c}878.12 \pm \\
20.66 *\end{array}$ & $\begin{array}{c}772.86 \pm \\
29.62 *\end{array}$ & $\begin{array}{c}1205.91 \pm \\
26.93 *\end{array}$ & $\begin{array}{c}1106.67 \pm \\
22.18^{*}\end{array}$ \\
\hline
\end{tabular}

Table 4. Total bilirubin content in blood serum ( $\mathrm{mkmol} / \mathrm{L})$ of rats affected by isoniazid, rifampicin and hexavalent chromium compounds, $(\mathrm{M} \pm \mathrm{m})$

\begin{tabular}{|c|c|c|c|c|c|c|}
\hline \multirow{2}{*}{ Group of animals } & \multicolumn{6}{|c|}{ Age group of animals } \\
\cline { 2 - 7 } & \multicolumn{2}{|c|}{ immature } & \multicolumn{2}{|c|}{ mature } & \multicolumn{3}{c|}{ senior } \\
\cline { 2 - 7 } & \multicolumn{4}{|c|}{ Research duration, days } \\
\cline { 2 - 7 } & \multicolumn{2}{|c|}{$7^{\text {th }}$} & $14^{\text {th }}$ & $7^{\text {th }}$ & $14^{\text {th }}$ & \multicolumn{2}{c|}{$7^{\text {th }}$} & $14^{\text {th }}$ \\
\hline intact control, $\mathrm{n}=6$ & \multicolumn{2}{|c|}{$12.19 \pm 0.55$} & $12.49 \pm 0.47$ & \multicolumn{2}{c|}{$15.09 \pm 0.78$} \\
\hline affected by potassium & $14.82 \pm$ & $17.97 \pm$ & $14.10 \pm$ & $16.53 \pm$ & $19.25 \pm$ & $20.97 \pm$ \\
dichromate, $\mathrm{n}=6$ & 0.98 & $1.13^{*}$ & 0.91 & $1.17^{*}$ & $1.27^{*}$ & $1.61^{*}$ \\
\hline affected by isoniazid and & $13.38 \pm$ & $18.68 \pm$ & $16.53 \pm$ & $17.53 \pm$ & $18.97 \pm$ & $19.25 \pm$ \\
rifampicin, $\mathrm{n}=6$ & 0.69 & $1.50^{*}$ & $1.17^{*}$ & $1.61^{*}$ & $1.12^{*}$ & $1.27^{*}$ \\
\hline affected by potassium & $16.97 \pm$ & $23.53 \pm$ & $23.10 \pm$ & $25.67 \pm$ & $23.82 \pm$ & $28.08 \pm$ \\
dichromate, isoniazid and & $1.62^{*}$ & $1.61^{*}$ & $1.55^{*}$ & $1.28^{*}$ & $1.09^{*}$ & $1.44^{*}$ \\
rifampicin, $\mathrm{n}=6$ & & & & & \\
\hline
\end{tabular}

by $13 \%$ and $20 \%$ higher than in the immature and senior animals, respectively.

The results of the research on the bile acids content in blood serum of the rats of all age groups are presented in table 5. In animals, which potassium dichromate was administrated to, the content of bile acids increased in all age groups $(p \leq 0.05)$. On the $7^{\text {th }}$ day of the research this rate increased by $35 \%$ in the immature animals, by $53 \%$ - in the mature animals and by $57 \%$ - in the senior animals if compared with the animals of the intact control. During the investigation of blood serum of the animals, which anti-TB drugs were administrated to, we evidenced a significant increase in bile acids content in the immature animals in 1.42 and 1.71 times on the $7^{\text {th }}$ and $14^{\text {th }}$ days of the research, respectively.
On the $7^{\text {th }}$ day in the mature and the senior animals the bile acids content increased in 1.54 and 1.76 times; on the $14^{\text {th }}$ day - in 1.50 and 1.80 times, respectively, in comparison with the animals of the intact control.

\section{Discussion}

It is established, that aminotransferases catalyze the reaction of transamination between the amino- and a-keto acids, take part in synthesis and forming of body proteins. The increasing activity of blood plasma enzymes, such as ALT and AST, demonstrates the level of hepatocytes damage and indicates liver disorders. Due to this thesis, we studied aminotransferase rate in blood serum and liver of the rats of different age groups affected by xenobiotics. In the liver of the rats after combined adminis- 
Table 5. Bile acids content in blood serum ( $\mathrm{g} / \mathrm{L}$ ) of rats affected by isoniazid, rifampicin and hexavalent chromium compounds, $(\mathrm{M} \pm \mathrm{m})$

\begin{tabular}{|c|c|c|c|c|c|c|}
\hline \multirow{4}{*}{ Group of animals } & \multicolumn{6}{|c|}{ Age group of animals } \\
\hline & \multicolumn{2}{|c|}{ immature } & \multicolumn{2}{|c|}{ mature } & \multicolumn{2}{|c|}{ senior } \\
\hline & \multicolumn{6}{|c|}{ Research duration, days } \\
\hline & 7th & 14th & 7th & 14th & 7th & 14th \\
\hline intact control, $n=6$ & \multicolumn{2}{|c|}{$6.95 \pm 0.43$} & \multicolumn{2}{|c|}{$9.48 \pm 0.58$} & \multicolumn{2}{|c|}{$12.02 \pm 0.64$} \\
\hline $\begin{array}{l}\text { affected by potassium } \\
\text { dichromate, } n=6\end{array}$ & $\begin{array}{l}9.36 \pm \\
0.68 *\end{array}$ & $\begin{array}{l}11.16 \pm \\
0.62 *\end{array}$ & $\begin{array}{l}14.50 \pm \\
0.50 *\end{array}$ & $\begin{array}{l}16.37 \pm \\
0.67 *\end{array}$ & $\begin{array}{l}18.33 \pm \\
0.98 *\end{array}$ & $\begin{array}{c}20.90 \pm \\
0.95 *\end{array}$ \\
\hline $\begin{array}{l}\text { affected by isoniazid and } \\
\text { rifampicin, } n=6\end{array}$ & $\begin{array}{l}9.90 \pm \\
0.49 *\end{array}$ & $\begin{array}{l}11.89 \pm \\
0.55^{*}\end{array}$ & $\begin{array}{l}14.60 \pm \\
0.81 *\end{array}$ & $\begin{array}{l}16.69 \pm \\
0.65^{*}\end{array}$ & $\begin{array}{l}18.09 \pm \\
0.87 *\end{array}$ & $\begin{array}{c}21.59 \pm \\
0.84 *\end{array}$ \\
\hline $\begin{array}{l}\text { affected by potassium } \\
\text { dichromate, isoniazid and } \\
\text { rifampicin, } n=6\end{array}$ & $\begin{array}{c}14.26 \pm \\
0.55^{*}\end{array}$ & $\begin{array}{c}16.61 \pm \\
0.43 *\end{array}$ & $\begin{array}{c}18.23 \pm \\
0.75 *\end{array}$ & $\begin{array}{c}21.37 \pm \\
0.87 *\end{array}$ & $\begin{array}{c}22.42 \pm \\
0.81 *\end{array}$ & $\begin{array}{c}24.16 \pm \\
0.95 *\end{array}$ \\
\hline
\end{tabular}

tration of toxicants we evidenced decrease in this enzyme rate, which indicated the cytolysis of hepatocytes and liver protein synthesis dysfunction in cases of affection by tuberculostatics and hexavalent chromium compounds. It was determined that the increase in ALT rate in blood serum was higher than in liver. It could be caused by toxic influence of potassium dichromate with underlying isoniazid- rifampicin affection of liver. The damaged liver cannot synthesize this enzyme because of hepatocytes damage and their release in blood serum; so we evidenced increased rate of this enzyme.

The determination of aminotransferase rate in blood serum is a sound indicator of the level of pathological process in liver. So we investigated AST rate. AST rate in blood serum increased and was the highest on the $14^{\text {th }}$ day of the research (in 3.7 times higher than the normal range) in the senior animals affected by chrome-isoniazid-rifampicin. The decrease in AST rate in liver proved the transamination of aspartate according to breaking of the Citric acid cycle and negligible release of protein enzyme from tissue cells into blood. It was determined that increase in alkaline phosphatase rate in blood serum of the rats of all age groups after the administration of the investigated toxins into their bodies cause the release of ALP out of the damaged hepatocytes as well as the restoration of its synthesis in bile tubules. We consider that this dynamic activity of alkaline phosphatase may evidence the development of hepatocytes destruction and intrahepatic cholestasis caused by liver architectonics damage and possible development of cirrhosis.

It was established that hepatotoxicity of the metabolites of isoniazid and rifampicin caused the lipid peroxidation of hepatocyte biomembranes and bile formation dysfunction. Rifam- picin can also inhibit the glucuronil-transaminases and cause bilirubin metabolism disorders and jaundice [10]. So, we had to examine total bilirubin content in blood serum of the animals affected by isoniazid, rifampicin and hexavalent chromium compounds. Increase in total bilirubin content under the influence of the toxicants evidenced the damage of cell membranes and erythrocytes predominantly and decrease in haemolysis as well as liver excretory dysfunction.

It was established, that in case of druginduced hepatitis the intestines and liver suffer from the affection, which was caused by the disorders of biosynthesis and hepatoenteral circulation of bile acids. After the combined administration of toxins (potassium dichromate, isoniazid and rifampicin) into the animals' bodies we evidenced that the highest level of bile acids content in immature rats was at the end of the experiment, $239 \%$, in comparison with the animals of the intact control. The increase in bile acids content in blood serum of the affected animals may have the toxic effect on hepatocyte mitochondria that caused increase in ions permeability to internal membrane of mitochondria, ions swelling and release of cytochrome $C$ into cytosol as well as cells apoptosis. The immature animals were the most sensitive to bile formation after administration of tuberculostatics and $\mathrm{K}_{2} \mathrm{Cr}_{2} \mathrm{O}_{7}$, although the increase in bile acids content was evidenced in the mature and senior animals.

\section{Conclusions}

We determined the increase in aminotransaminases and alkaline phosphatase rate in blood serum and their decrease in liver. It proved the toxic effect of hexavalent chromium compounds and tuberculostatics on the body of animals of all ages. It caused the disorder of 
hepatocyte plasmatic membranes permeability, which was evidenced by significant amount of enzymes in blood and caused liver inflammatory process in the affected animals. So, cholestasis developed. It was characterized by accumulation of bile acids and total bilirubin as well as other

\section{References}

1. Буеверов АО. Лекарственный гепатит: если препарат нельзя отменить. Клинические перспективы гастроэнтерологии и гепатологии 2007; 5: 13-19.

2. Рахимов КД, Пальгова ЛК, Аленова АХ. Справочник по побочным действиям лекарственных средств. Алматы; 2004: 224.

3. Santhosh S, Sini T, Anandan R. Hepatoprotective activity of chitosan against isoniazid and rifampicininduced toxicity in experimental rats. Eur J Pharmacol 2007; 572: 69-73.

4. Посохова КА, Шевчук ОО, Дацко ТВ. Порівняльна гепатотоксичність антимікобактеріальних засобів та їх комбінацій. Фармакологія та лікарська токсикологія 2010; 5: 41-46.

5. Gliman AG. Antimicrobial agents: drugs used in the chemotherapy of tuberculosis, in Goodman and Gilman's the pharmacologic basis of therapeutics. New York. Pergamon Press; 1990: 1149-1152.

6. Yew WW, Leung CC. Antituberculosis drugs and hepatotoxicity. Respirology 2006; 11: 699-707.

7. Sarich T, Youssefi M, Zhou T. Role of hydrazine in the mechanism of isoniazid hepatotoxicity in rabbits. Arch Toxicol 1996; 70: 835-840.

8. Schwab $C$, Tuschl $H$. In vitro studies on the toxicity of isoniazid in different cell lines. Human and Experimental Toxicology 2003; 22: 607-615.

9. Гоженко АИ. Влияния рифампицина на функциональное состояние почек белых крыс. Нефрология 2005; 2: 101-103.

10. Пятночка IT, Медвідь ЛI, Корнага СІ. Гостра нирково-печінкова недостатність - ускладнення bile components in blood that could inhibit the synthesis of components complement in hepatocytes. The most pronounced metabolic disorders in cases of chrome-isoniazidrifampicin affection were evidenced in body of the animals of immature and senior age in comparison with mature animals. лікування рифампіцином. Інфекційні хвороби 2002; 2: 104-106.

11. Трахтенберг IM, Короленко ТК, Коршун ММ. Експериментальне вивчення впливу важких металів на організм тварин різних вікових груп. Гигиена труда 2004; 35: 158-170.

12. Duffus JH. Heavy metals - a meaningless term? Pure and Applied Chemistry 2002; 74: 793807.

13. Recommended health-based limits in occu pational exposure to heavy metals. Geneva: WHO, 1980: 205.

14. Hantson P, Caenegem O, Decordier I. Hexavalent chromium ingestion: biological markers of nephrotoxicity and genotoxicity. Clin. toxicol. (Phila) 2005; 43: 111-112.

15. Maeng SH, Chung HW, Kim KJ. Chromosome aberration and lipid peroxidation in chromiumexposed workers. Biomarkers 2004; 9: 418-434.

16. Guide for the care and use of laboratory animals: Eighth edition. The National Academies Press, Washington, DC. - 2011.

17. Reitman S, Frankel S. Definition of biochemical indicators of the toxicity of liver. Amer J Clin. Path 1957; 28: 56-60.

18. Гонський ЯІ, Саяк НП, Рубіна ЛМ. Біологічна хімія. Лабораторний практикум. Тернопіль. Укрмедкнига; 2001: 287.

19. Лапач СН, Чубенко АВ, Бабич ПН. Статистические методы в биологических исследованиях с использованием Excel. Київ. Морион; 2000: 320. 